\title{
Research on the issue of using the heat of combustion products for heat supply of greenhouses
}

\author{
Serdar Nazarov ${ }^{1, *}$, Muhammetberdi Rakhimov ${ }^{1}$, and Saparmyrat Hojageldiyev ${ }^{1}$ \\ ${ }^{1}$ State Energy Institute of Turkmenistan, st Bayramhan 62, c. Mary 745400, Turkmenistan
}

\begin{abstract}
Cultivation of agricultural crops in winter season is carried out in special greenhouses. For heating greenhouses, a huge amount of heat energy is consumed. In the conditions of Turkmenistan, up to 1500 tons of standard fuel per year is consumed to heat the greenhouse with an area 1 hectare. The increase in heating costs leads to an increase in the prices of grown products. Therefore, saving fuel energy in the greenhouses is one of the most important economic factors. Possibilities of using the heat of the combustion products of steam boilers at the Mary State Electric Power Station (Turkmenistan) for heating greenhouses are discussed in the article. For this purpose, a special contact heat exchanger is installed on the line of the outgoing combustion products of steam boilers. In the experimental facilities, water is injected from top to bottom, and combustion products move in the opposite direction. In this case, the temperature of the combustion products decreases from $120-150{ }^{\circ} \mathrm{C}$ to $30-40{ }^{\circ} \mathrm{C}$. The temperature of the cooling water of the combustion products rises from $10-20{ }^{\circ} \mathrm{C}$ to $40-45^{\circ} \mathrm{C}$. To increase the contact surface of water and gas in a contact heat exchanger, spray-type layer conductor is used. A distinctive feature of the experimental facility is the use of local materials as a spray-type layer with a conductor. For subsoil heating of greenhouses, water is supplied with the temperature of $40^{\circ} \mathrm{C}$, and for the raise of the vegetables grown in them water is supplied with the temperature of $22-25^{\circ} \mathrm{C}$. The use of the heat of combustion products to heat greenhouses is of great importance both for saving fuel and for purifying the environment from harmful emissions.
\end{abstract}

\section{Introduction}

Cultivation of agricultural crops in winter season is carried out in special greenhouses. For heating greenhouses, a huge amount of heat energy is consumed. The increase in heating costs leads to an increase in the prices of grown products. Therefore, saving fuel energy in greenhouses is one of the most important economic factors.

Water, air, infrared and electric heaters are used for heating air and soil in greenhouses. The main disadvantages of water heaters are their large consumption of fuel to heat the water supplied to the greenhouse, and a high risk of freezing the system. Antifreeze liquids can be used, but it increases costs as well. In the air system, the coolant has no risk of freezing, but due to the low heat capacity of the air, the efficiency of heating air in the greenhouses is low. The main disadvantage of the electric heater system is the high cost of heating the heat carriers. The advantage of an infrared gas heating system is that it first heats the soil and then the air inside the greenhouse. On the other hand, the $\mathrm{CO}_{2}$ caused by the fuel accelerates the growth of plants, but the disadvantage of the infrared gas heating

system is the need for a special gas supply project and the high cost of equipment. One of the main problems with greenhouse heating systems is maintaining a balance between heating the air inside the greenhouse and heating the soil. Due to the high heat capacity of the soil, a large amount of heat is consumed to heat it. Without raising the soil temperature, it is impossible to improve the quality and fruitfulness of the harvested crop [3]. Therefore, it is advisable to heat greenhouses with subsoil heating.

\section{Literature review}

In work [1], experimental studies on the use of heat from the combustion products of natural gas for heat supply of greenhouses with subsurface heating were carried out. During the experiments, it was found that the annual heat consumption of the greenhouse complex with an area of 6 hectares is about 40 thousand GJ, where about $10 \%$ is spent on heating the irrigation water.

In article [2], mathematical models of heat engineering calculations for a trench-type greenhouse were developed to determine the temperature of leaves and air. It was implemented on the basis of mathematical models and developed geoinformation system of the zoning map, compiled nomograms for the regions of the Turkmenistan to predict the air temperature in the greenhouse, depending on solar radiation by months of the year.

For underground heating of greenhouses, various materials, such as polyethylene and asbestos-cement

*orresponding author: marytdei@mail.ru 
pipes, slate channel, monolithic concrete channel, and brick can be used. In work [3], a feasibility study for the use of a monolithic concrete channel for subsurface heating of greenhouses was carried out and its effectiveness was confirmed by an experiment. The advantage of a concrete channel in comparison with the other types of materials is that it has a lower cost, high heat transfer coefficient and heat capacity, but the disadvantage is the length of its installation period. An experiment carried out on subsoil heating of soil and air in a greenhouse revealed that the temperature difference between the air inside and outside the greenhouse is 23.5 ${ }^{\circ} \mathrm{C}$, while the outside air temperature of a sunny day changes from $-18^{\circ} \mathrm{C}$ to $-29^{\circ} \mathrm{C}$.

In addition to fossil fuels such as coal, oil and natural gas, much attention is paid to secondary energy resources and renewable energy sources $[4,5]$. In $[6,7]$, the efficiency of an annular heat pump system for heating greenhouses is determined. The annular heating system of greenhouses includes two heat pumps HP1 and HP2, a heat accumulator, a circulation pump and an autonomous heating system. Heat pump HP2 is designed to perform heat supply to the system from the soil collector. Heat pump HP1 is designed to transfer heat to circulating water, and then to the heat energy accumulator through a circulating pump using a side airwater collector when the air inside the greenhouse overheats. With the help of the heat pump HP1, $70 \%$ of the excess heat energy generated during overheating of the air inside the greenhouse is transferred to the heat accumulator. During summer months, the greenhouse can be fully heated using the annular system. In the autumn-spring months, in the absence of sufficient heat supply to the greenhouse with a heat pump, an autonomous heating system is put into operation. The heat of the annular system can be used to heat the air and soil inside the greenhouse and to irrigate plants during the cold season.

The steady rise in fuel and electricity prices leads to a decrease in the profitability of products produced in the greenhouses. The main factor affecting the rise in prices for the manufacturing of products is the share of costs for supplying greenhouses with electricity and heat. It is possible to increase the profitability of the product by installing new energy-saving innovative greenhouses, but it is impossible to reconstruct all greenhouses in a short time. The article [8] analyzes the energy consumption for growing vegetables at the greenhouse complex "Zavyalovskiy" JSC (joint stock company) in the Udmurt Republic of the Russian Federation. The analysis revealed the main costs of growing vegetables: the amount of electricity for irradiation, the amount of water for irrigation, the amount of heat for heating and ventilation. It is possible to reduce the energy intensity of greenhouses by using optimal substrates. The Zavyalovskiy JSC (joint stock company) greenhouse plant states that energy resources can be saved by using a substrate based on a flax fire. The high moisture content of this substrate allows saving the amount of water used for watering vegetables, as a result, a shorter pump life, as well as a decrease in the heat energy consumed by underground heating can be achieved. When using a substrate based on flax fire, 1.1 thousand $\mathrm{m}^{3}$ of fuel can be saved in 7 weeks, which gives 1 GJ of heat energy.

Greenhouse technologies for growing vegetables are divided into two groups: translucent and opaque. In [9], methods of efficient use of heat energy generated by irradiators in opaque greenhouses are considered. With the help of a fan, the forced air flow is heated with the heat energy generated by the irradiators, and its heat is consumed to heat the grown vegetables. If the air temperature inside the greenhouse exceeds the required one, the heat of the hot air is consumed to heat the water of the heat accumulator. When the irradiators are turned off (for example, at night), hot water from a heat accumulator is used to heat the air inside the greenhouse. This method reduces the energy consumption of the product to $112.7 \mathrm{kWh} / \mathrm{kg}$, and the energy consumption to $505.82 \mathrm{kWh}$. The article [10] also shows the energy efficiency of using heat energy of the irradiators of greenhouses. As a result of forced air movement by means of a fan, the average specific installed power of the irradiation system is reduced by $6 \%$.

The article [11] discusses the modeling of energy supply for greenhouses with an area of $1050 \mathrm{~m}^{2}$. A natural ventilation system was installed in the greenhouse, based on the closing and opening of window openings, front windows and a heating system using a 15 $\mathrm{kW}$ electric heater. The results show that at certain hours of the night, it is necessary to heat the air in the greenhouse for 206 days. January was the month with the highest energy consumption, requiring the introduction of five more heaters with the same conditions to meet the energy demand and maintain 12 ${ }^{\circ} \mathrm{C}$ temperature. This means that for heat comfort in the microclimate of the greenhouse, a device with an output of $85.56 \mathrm{~kW}$ is required. During winter time in Central Mexico (December 21 to March 21), energy consumption per year is about $63 \%$ of the total, which serves to maintain the greenhouse temperature at night to $12{ }^{\circ} \mathrm{C}$.

The article [12] proposed a model of a greenhouse a flower greenhouse, which is part of a large garden complex. The walls and roof of the analyzed greenhouse are made of glass elements with a thickness of $3 \mathrm{~mm}$ and a layer of bubble film with a thickness of $5 \mathrm{~mm}$, which are separated from each other by a layer of air $10 \mathrm{~mm}$ thick. The heat balance is aimed at determining the losses and heat inflow of each partition in the object under study. For this, the calculation of losses along the lateral surface, the upper surface and the soil of the greenhouse, as well as the power of the heat energy of solar radiation, which reaches the object on sunny days, is performed. Due to legal regulations regarding environmental protection, as well as the general interest in the use of heat pumps, it was decided to use and analyze soil and air heat pumps in the greenhouses. The rated power of the selected glycol-water soil heat pump was $21.5 \mathrm{~kW}$. When comparing the cost of the heating system operation using a soil source heat pump with the existing heating system using a coal-fired boiler, the heating system's annual profit reached $62 \%$.

The article [13] substantiates the choice of the parameters of the equipment to create a control model 
for combined heating of a greenhouse when growing plants in the greenhouses. Calculations of the heat consumption of indoor systems, and options for using different types of greenhouse heating were performed. According to the results of the calculations, combined heating is the best option for the small and medium-sized systems for growing vegetables in the greenhouses.

In article [14] calculation methods for a winter greenhouse with the combined system of heating was developed. It includes overhead infrared irradiators with the convective heaters and is intended for the support of the necessary warm-humid conditions of the placement and the soil in the sowing placement.

\section{Materials and methods}

The article discusses the possibilities of using the heat of the combustion products of steam boilers at the Mary State Electric Power Station (Turkmenistan) for heating greenhouses. For this, a special contact heat exchanger is installed on the line of the exhaust gas outlet of the steam boiler. In a pilot plant, water is injected from top to bottom, and combustion products move in the opposite direction. To increase the contact surface of water and gas in a contact heat exchanger, a spray-type layer conductor is used. A distinctive feature of the experimental setup is the use of local material such as spray-type layer conductor [15]. The experimental setup (Fig. 1) consists of an economizer body (vertical pipe) (1) with a diameter of $200 \mathrm{~mm}$, a low-power smoke exhauster (2), a water injection device (3), a conductor (4), a drainage base (5), thermometers pockets installed on pipelines of cold and heated water (10), thermocouples installed on hot and cooled gas pipelines (11), drain tap (15), The experimental setup operates in the order described below. The flue gases entering the inlet (6) of the heat exchanger, passing through the spray-type layer conductor (4), leave through the outlet of flue gases (7). To keep the materials in the irrigated layer of the installation, a support grid (14) is fixed. Water, passing through the cold water inlet (8), is supplied to the injection device (3). Passing through the spray-type layer conductor, the water comes into contact with the flue gases, heats up and flows out through the heated water outlet (9). A hatch (13) is provided for outside observation of the processes taking place in the irrigated bed, and a flange connection (12) is provided for replacing the spray-type layer conductor.

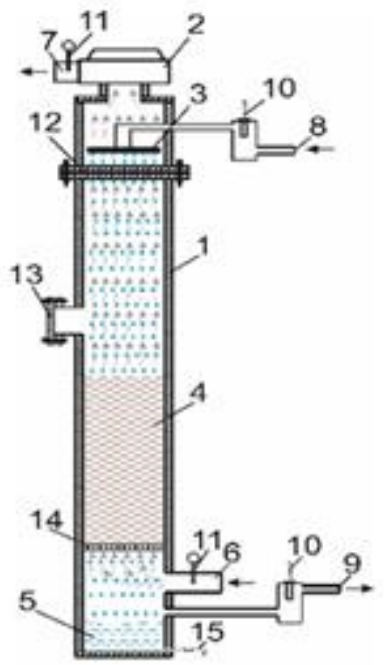

Fig. 1. The experimental setup installed at the Mary State Electric Power Station ( 1 - economizer body (vertical pipe); 2 - low-power smoke exhauster; 3 - a water injection device; 4 spray-type layer conductor; 5 - drainage base; 6 - flue gas inlet; 7 - outlet of flue gases; 8 - cold water inlet; 9 - heated water outlet; 10 - thermometers pockets installed on pipelines of cold and heated water; 11 - thermocouples installed on hot and cooled gas pipelines; 12 - flange connection; 13 - hatch; 14 - support grid; 15 - drain ta).

In the experimental installation, the temperature of the combustion products decreases from $120-150{ }^{\circ} \mathrm{C}$ to $30-40{ }^{\circ} \mathrm{C}$, the temperature of the cooling water rises from $10-20{ }^{\circ} \mathrm{C}$ to $45-55^{\circ} \mathrm{C}$.

In the experimental installation, the temperature of the combustion products decreases from $120-150{ }^{\circ} \mathrm{C}$ to $30-40{ }^{\circ} \mathrm{C}$, the temperature of the cooling water rises from $10-20{ }^{\circ} \mathrm{C}$ to $45-55^{\circ} \mathrm{C}$.

Various vegetables are grown in the subsidiary farm of the Mary State Electric Power Station in 22 greenhouses with a total area of 1 hectare. There are tomatoes in 10 greenhouses with an area of 0.45 ha, cucumbers in 6 greenhouses with an area of 0.27 ha, bell peppers in 1 greenhouse with an area of 0.045 ha, and eggplants in 1greenhouse also with an area of 0.045 ha, and lemons in 4 greenhouses with an area 0.18 ha. All greenhouses are located directly next to each other. The interior of the greenhouses is divided by a glass partition into three sections, depending on the required temperature. The optimum air temperature inside the greenhouse planted with tomatoes and cucumbers in section I is $20^{\circ} \mathrm{C}$, the temperature inside the greenhouse planted with bell peppers and eggplants in section II is $18^{\circ} \mathrm{C}$, and the temperature inside the greenhouse planted with lemons in section III is $12{ }^{\circ} \mathrm{C}$. Figure 2 displays a general view of the greenhouse fence, and Table 1 displays its dimensions and characterizing parameters. 


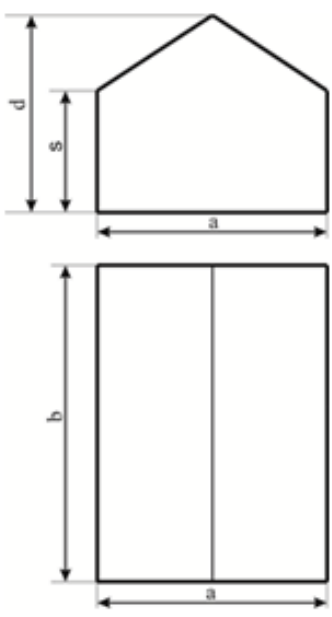

Fig. 2. General view of the external fence of the greenhouse.

The use of heat from the combustion products of electric power stations for heating greenhouses is an important element of energy saving. One of the main tasks for maintaining a favorable microclimate in the greenhouse is the development of a mathematical model of energy supply.

Table 1. Greenhouse dimensions and features.

\begin{tabular}{|c|c|c|}
\hline $\begin{array}{l}\text { Parts of } \\
\text { the facility }\end{array}$ & Dimensions & $\begin{array}{c}\text { Numerical } \\
\text { value }\end{array}$ \\
\hline \multirow{5}{*}{$\begin{array}{l}\text { Greenhouse } \\
\text { dimensions }\end{array}$} & Width, a, mm & 6500 \\
\hline & Length, $b, \mathrm{~mm}$ & 70000 \\
\hline & Sidewall height, s, mm & 2500 \\
\hline & Center height, $\mathrm{d}, \mathrm{mm}$ & 3500 \\
\hline & $\begin{array}{c}\text { Greenhouse quantity, } \\
\text { n, pieces }\end{array}$ & 22 \\
\hline \multirow{3}{*}{$\begin{array}{l}\text { Glass } \\
\text { external } \\
\text { wall }\end{array}$} & $\begin{array}{l}\text { Glass wall thickness, } \\
\delta_{\text {glass }}, \mathrm{m}\end{array}$ & 0.003 \\
\hline & $\begin{array}{c}\text { Heat conductivity } \\
\text { coefficient, } \lambda_{\text {glass }}, \frac{\mathrm{W}}{\mathrm{m}^{2} \cdot \mathrm{K}}\end{array}$ & 0.8 \\
\hline & $\begin{array}{l}\text { Coefficient of heat emission } \\
\text { through glass, } \tau_{\text {glass }}\end{array}$ & 0.82 \\
\hline \multirow{2}{*}{ Sidewalls } & Sidewall square, $\mathrm{F}_{\text {side }}, \mathrm{m}^{2}$ & 350 \\
\hline & $\begin{array}{l}\text { Typical linear dimensions } \\
\text { of sidewall, } \mathrm{L}_{\text {side }}, \mathrm{m}\end{array}$ & 2.5 \\
\hline \multirow{2}{*}{$\begin{array}{l}\text { Front and } \\
\text { back walls }\end{array}$} & $\begin{array}{l}\text { Front and back walls } \\
\text { square, } F_{\text {front }}, \mathrm{m}^{2}\end{array}$ & 858 \\
\hline & $\begin{array}{l}\text { Typical linear dimensions } \\
\text { of front and back walls, } \\
\qquad \mathrm{L}_{\text {front }}, \mathrm{m}\end{array}$ & 3 \\
\hline \multirow{2}{*}{ Soil } & $\begin{array}{l}\text { Protected soil square of } \\
\text { greenhouse, } \mathrm{F}_{\text {soil }}, \mathrm{m}^{2}\end{array}$ & 10000 \\
\hline & $\begin{array}{c}\text { Soil conductivity } \\
\text { coefficient, } \lambda_{\text {soil }}, \frac{\mathrm{W}}{\mathrm{m}^{2} \cdot \mathrm{K}}\end{array}$ & 1.49 \\
\hline \multirow{2}{*}{ Roof } & Roof square, $\mathrm{F}_{\text {roof }}, \mathrm{m}^{2}$ & 10010 \\
\hline & $\begin{array}{l}\text { Typical linear dimensions } \\
\text { of the roof, } \mathrm{L}_{\text {roof }}, \mathrm{m}\end{array}$ & 3.40 \\
\hline
\end{tabular}

To draw up this model, they are guided by the heat balance. The heat balance, in its turn, is expressed as follows:

$$
\mathrm{Q}=\left(\mathrm{Q}_{\text {side }}+\mathrm{Q}_{\text {front }}+\mathrm{Q}_{\text {roof }}+\mathrm{Q}_{\text {soil }}+\mathrm{Q}_{\text {vent }}\right)-\mathrm{Q}_{\text {rad }}
$$

where: $\mathrm{Q}_{\text {side }}-$ heat losses of the side wall, $\mathrm{W} ; \mathrm{Q}_{\text {front }}$ heat losses of the front and back walls, $\mathrm{W} ; \mathrm{Q}_{\text {roof }}$ roofing heat losses, $\mathrm{W} ; \mathrm{Q}_{\text {soil }}$ - heat losses of the soil, $\mathrm{W}$ ; $\mathrm{Q}_{\mathrm{vent}}$ - heat losses consumed by ventilation air; $\mathrm{W}$; $\mathrm{Q}_{\mathrm{rad}}$ - the amount of heat passing into the greenhouse with the help of solar radiation, $\mathrm{W}$.

Heat losses of the front and rear walls are determined as follows [11]:

$$
\mathrm{Q}_{\text {wall }}=\kappa_{\text {wall }} \cdot \mathrm{F}_{\text {wall }} \cdot\left(\mathrm{T}_{\text {in.air }}-\mathrm{T}_{\text {out.air }}\right)
$$

where: $\mathrm{T}_{\text {in.air }}, \mathrm{T}_{\text {out.air }}$ - air temperature inside and outside the greenhouse, $\mathrm{K} ; \mathrm{F}_{\text {wall }}-$ the area of the walls, $\mathrm{m}^{2} ; \mathrm{\kappa}_{\text {wall }}-$ heat transfer coefficient, $\frac{\mathrm{W}}{\mathrm{m}^{2} \cdot \mathrm{K}}$. The heat transfer coefficient is determined by the following formula:

$$
\kappa_{\text {wall }}=\frac{1}{\frac{1}{\alpha_{\text {in }}}+\frac{\delta_{\text {glass }}}{\lambda_{\text {glass }}}+\frac{1}{\alpha_{\text {out }}}}
$$

here: $\delta_{\text {glass }}-$ glass wall thickness (shown in table 1 ), $\mathrm{m}$; $\lambda_{\text {glass }} ;-$ coefficient of heat conductivity of the glass wall (given in table 1) $\frac{\mathrm{W}}{\mathrm{m} \cdot \mathrm{K}} ; \alpha_{\text {in }}$ - coefficient of heat transfer of internal air to the inner surface of the wall inside the greenhouse, $\frac{\mathrm{W}}{\mathrm{m}^{2} \cdot \mathrm{K}} ; \alpha_{\text {out }}-$ is the coefficient of heat transfer from the outer surface of the wall to the outside air, $\frac{\mathrm{W}}{\mathrm{m}^{2} \cdot \mathrm{K}}$ the value $\alpha_{\text {out }}$ is determined by the following criterion equation:

$$
\mathrm{Nu}_{\text {out }}=0.644 \cdot \mathrm{Re}_{\text {out }}^{0.5} \cdot \operatorname{Pr}_{\text {out }}^{0.33}
$$

where: $\mathrm{Pr}_{\text {out }}-$ Prandtle number for outdoor air; $\mathrm{Re}_{\text {out }}$ Reynolds number for outdoor air, which is calculated as follows:

$$
\mathrm{Re}_{\text {out }}=\frac{\mathrm{w} \cdot \mathrm{L}}{v_{\text {out }}^{2}}
$$

here: $w$ - air velocity outside the greenhouse, its average value according to metrological data, $w=3 \frac{\mathrm{m}}{\mathrm{s}}$; $\mathrm{L}$ - characteristic linear dimensions (shown in Table 1), $v_{\text {out }}^{2}$ - coefficient of kinematic viscosity of air, $\frac{\mathrm{m}^{2}}{\mathrm{~s}}$.

The value $\alpha_{\text {in }} n$ is determined by the following criterion equation:

$$
\mathrm{Nu}_{\mathrm{in}}=0.516 \cdot\left(\mathrm{Gr}_{\text {in }} \cdot \operatorname{Pr}_{\text {in }}\right)^{0.25}
$$


where: $\mathrm{Gr}_{i n}$ - is the Grashof criteria for the air inside the greenhouse, which is determined in the following way:

$$
\mathrm{Gr}_{\text {in }}=\frac{\mathrm{g} \beta\left(\mathrm{T}_{\text {in.air }}-\mathrm{T}_{1}\right) \mathrm{L}^{3}}{v_{\text {in }}^{2}}
$$

where: $T_{1}-$ is the temperature of the inner surface of the outer wall, $\mathrm{K} ; \beta$ - air compressibility, this value is determined as follows:

$$
\beta=\frac{1}{\frac{\mathrm{T}_{\text {in.air }}-\mathrm{T}_{1}}{2}}
$$

The heat transfer coefficient is found as follows:

$$
\alpha=\mathrm{Nu} \frac{\lambda}{\mathrm{L}}
$$

The heat transfer coefficient for the roof is increased by $30 \%$ compared to the coefficient calculated for the side surface. In this case, the roof heat loss is calculated using this formula:

$$
\mathrm{Q}_{\text {roof }}=1.3 \cdot \alpha_{\text {roof }} \cdot \mathrm{F}_{\text {roof }} \cdot\left(\mathrm{T}_{\text {in.air }}-\mathrm{T}_{\text {out.air }}\right)
$$

The following criterion equation is used to determine the amount of heat lost by the soil:

$$
\mathrm{Nu}_{\text {soil }}=0.135 \cdot\left(\mathrm{Gr}_{\text {soil }} \cdot \mathrm{Pr}_{\text {soil }}\right)^{0.25}
$$

Grashof's criteria are defined as follows:

$$
\mathrm{Gr}_{\text {soil }}=\frac{g \beta\left(\mathrm{T}_{\text {in.air }}-\mathrm{T}_{\text {soil }}\right) \mathrm{L}_{\text {soil }}^{3}}{v_{\text {air }}^{2}}
$$

where: $\mathrm{T}_{\text {soil }}-$ soil temperature, which can be considered equal to the outside air temperature [11]. Thus, the heat transfer coefficient is determined:

$$
\alpha_{\text {soil }}=\mathrm{Nu}_{\text {soil }} \frac{\lambda_{\text {soil }}}{\mathrm{L}_{\text {soil }}}
$$

The amount of heat passing into the greenhouse using solar radiation is calculated using the following definition:

$$
\mathrm{Q}_{\mathrm{rad}}=\eta \cdot \mathrm{I}_{\mathrm{c}} \cdot \mathrm{F}_{\mathrm{rad}} \cdot \tau
$$

where: $\eta$ - efficiency of conversion of the beam heat, equal to $\eta=0.7 ; I_{c}-$ radiation intensity, $\frac{W}{\mathrm{~m}^{2}} ; \tau-$ heat radiation transmittance, the value of which is given in Table 1. It was assumed that solar radiation reaches half of the roof area:

$$
\mathrm{F}_{\mathrm{rad}}=\mathrm{b} \cdot \mathrm{L}_{\mathrm{roof}}
$$

Heat losses consumed in ventilation air are determined as follows:

$$
Q_{\text {vent }}=\frac{F_{\text {vent }}}{R_{\text {vent }}}\left(T_{\text {in.air }}-T_{\text {out.air }}\right)
$$

where: $\mathrm{F}_{\mathrm{vent}}$ - coverage area, $\mathrm{m}^{2} ; \mathrm{R}_{\text {vent }}-$ heat resistance, which is equal to $\mathrm{R}_{\text {vent }}=0.5 \frac{\mathrm{m}^{2} \cdot \mathrm{K}}{\mathrm{W}}$.

The calculation of the mathematical model of the greenhouse heat supply was carried out in the Mathcad 15 program. The calculation was carried out for three sections, separated into the greenhouses by a glass wall. Despite the fact that different temperatures are required in the sections, the use of one heat source is provided for their heat supply. To provide three sections with different temperatures with one heat source, a heating surface area is selected for each.

\section{Discussions of results}

As a result of the computational study, the amount of heat required to heat the greenhouse in sections in winter months was determined. The average monthly ambient temperature was used in the calculations. Fig. 3 displays the amount of heat required to keep section I at $20{ }^{\circ} \mathrm{C}$ during winter months. As it is seen from the graph, a large amount of heat is needed to heat the greenhouse in January. From April to the end of September, there is no need for additional heating of the greenhouses.

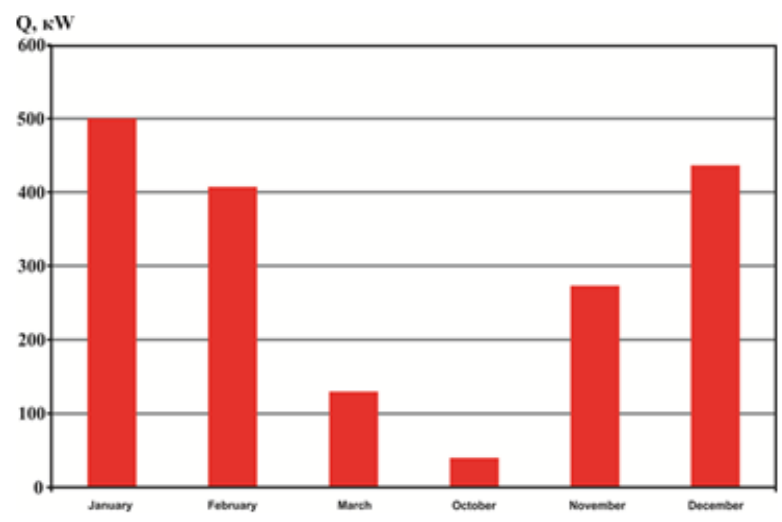

Fig. 3. The consumed heat energy in section I to maintain the required air and soil temperature inside greenhouses $\left(20^{\circ} \mathrm{C}\right)$ during the cold season.

Fig. 4 displays the amount of heat required to maintain temperature at $18{ }^{\circ} \mathrm{C}$ in section II, and Fig. 5 displays the amount of heat required to maintain temperature at $12{ }^{\circ} \mathrm{C}$ in section III. As it is seen from these graphs, it is generally necessary to provide the greenhouse with additional heating in January, February and December in order to maintain the air temperature inside the greenhouse at $18{ }^{\circ} \mathrm{C}$ and $12{ }^{\circ} \mathrm{C}$. In spring and autumn, that is, in April and November, the additional heating provided for heating the greenhouse does not stop completely, because only the average monthly temperature is taken into account in the calculations, and the decrease in temperature at night is not taken into account. 


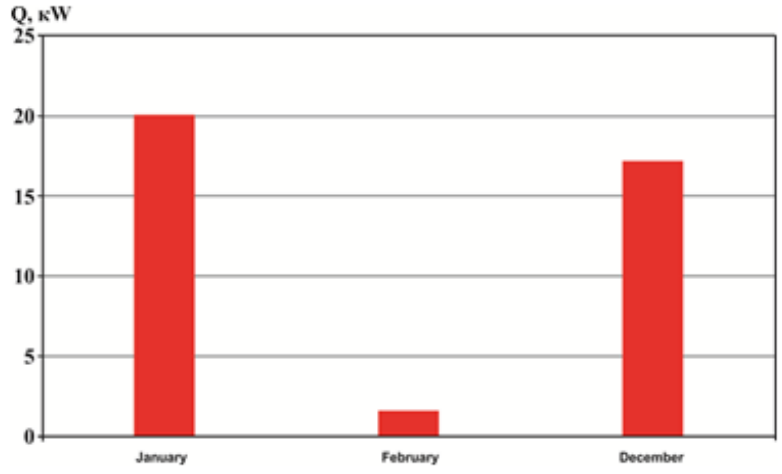

Fig. 4. The consumed heat energy in section II to maintain the required air and soil temperature inside greenhouses $\left(18^{\circ} \mathrm{C}\right)$ during the cold season.

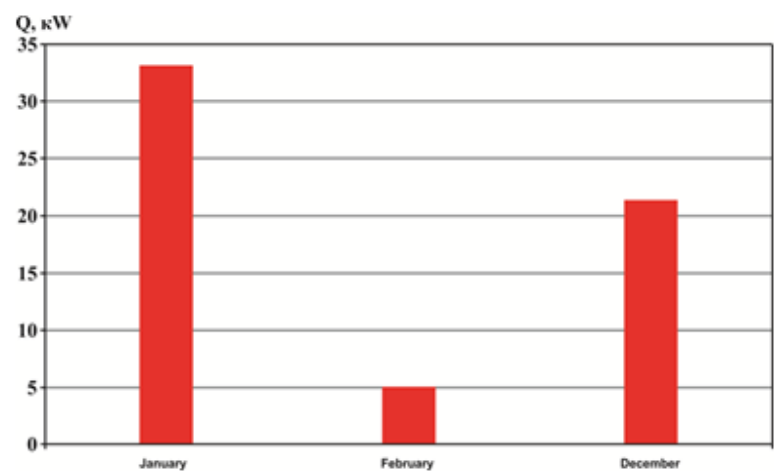

Fig. 5. The consumed heat energy in section III to maintain the required air and soil temperatures inside greenhouses $\left(12^{\circ} \mathrm{C}\right)$ during the cold season.

As it is seen from the calculations, $20-30 \%$ of the heat loss happens from the outer wall, $16-17 \%$ from the surface of the soil and 50-60\% from the ventilation air. Using the graphs above, the required amount of hot water and heating surface area for subsoil heating of greenhouses in sections I, II and III can be determined.

\section{Conclusion}

As a result of the experiment of using the heat of combustion products of electric power plants, hot water can be used to heat greenhouses, since the temperature of hot water in it reaches $55^{\circ} \mathrm{C}$. And the water temperature at $40{ }^{\circ} \mathrm{C}$ is sufficient for subsoil heating of greenhouses. On the example of a greenhouse in the subsidiary farm of the Mary State Electric Power Station, a mathematical model of its heat supply has been implemented. According to the results of a mathematical model of energy supply to greenhouses in winter season, the required amount of heat energy in sections of greenhouses, divided into three parts, for the simultaneous cultivation of various vegetables was determined.

\section{References}

1. DI Karas, ST Mosin. Using the heat of flue gases from boilers for heat supply to greenhouses. Industrial energy, 1988, No. 5.

2. AM Pendzhiev. Energy efficiency of energy resources and climatic zoning of solar greenhouses. // Aeconomics: Economics and Agriculture, 2017. No. 9 (21). http://aeconomy.ru/science/agro/energoeffektivnostenergeticheskikh/

3. V.A. Kubis. Design and operation experience of energy efficient greenhouses (on the example of the Penza region) (Monograph) Penza: PGUAS, 2014. P. 128.

4. M.A. Taimarov, V.K. Ilyin, A.L. Osipov, A.N. Dolgova, A.V. Akhmerov. Heat pump complex for utilization of secondary energy resources of petrochemical plants // News of higher educational institutions. Energy Problems. 2019.Vol. 21.No. 3-4 P. 7-14.

5. I. Khallyev, K.Kh. Gilfanov. Reducing the cost of the heat pump system of heat supply by replacing the primary circuit collector // News of higher educational institutions. Energy Problems. 2020.Vol. 22.No. 1.P. 28-37.

6. VA Kozhukhov, AF Semenov. Development of a system for accumulating thermal energy in a greenhouse using heat pumps. Bulletin of KrasGAU, 2008, №3

7. Abramov S.B., Suvorov I.F. (Russian Federation) Development of an efficient system of heating greenhouses under conditions of transbaikal region /LXIII International correspondence. Scientific and practical conference «International scientific review of the problems and prospects of modern science and education» (Boston. USA. October 22-23, 2019)

8. I.Yu. Chazova, O. G. Debt. Study of the possibilities of reducing the energy intensity of greenhouse products. Bulletin of the Izhevsk State Agricultural Academy. Scientific and practical journal. No. 1 (30) 2012.

9. Dolgikh P.P. Dotsenko D.S. Evaluation of the efficiency of a greenhouse irradiator with forced cooling // Vestnik NGIEI. - 2018. - No. 10 (89). - P. 29-44.

10. I.A. Fedorova. Heat improvement by managing the power supply. International Journal of Humanities and Natural Sciences, vol.10-1 (37), 2019.

11. Cruz Ernesto Aguilar-Rodriguez, Jorge FloresVelazquez, Waldo Ojeda-Bustamante, Fernando Rojano, Mauro Iñiguez-Covarrubias Valuation of the Energy Performance of a Greenhouse with an Electric Heater Using Numerical Simulations. Inf. Process. Agric. 2020, 8-600. [CrossRef]

12. Artur Nems', Magdalena Nems, Klaudia Swider Analysis of the Possibilities of Using a Heat Pump for Greenhouse Heating in Polish Climatic 
Conditions-A Case Study. Sustainability 2018, 10, 3483. [CrossRef]

13. S.A Ivanov, I. Yu. Kvyatkovskaya, AF Dorokhov, ND Shishkin. Model of a control system for combined heating of a greenhouse in greenhouse conditions based on the RASPBERRY PI microcontroller. AGTU Bulletin. Ser .: Management, computer technology and informatics. 2015. No. 2

14. Pavlov, M.V., Karpov, D.F., Sinitsyn, A.A., Gudkov, A.G. Winter greenhouse combined heating system. Magazine of Civil Engineering. 2020. 95(3). P. 131-139. DOI: 10.18720/MCE.95.12

15. A. Rakhmanov, S. Khojageldiev. Experimental study of the use of local materials for the irrigated layer of the heat exchanger. Science and technology in Turkmenistan, 2020, No.1. 